\title{
Land-use influences the distribution and activity of high affinity CO-oxidizing bacteria associated to type l-coxL genotype in soil
}

\author{
Liliana Quiza, Isabelle Lalonde, Claude Guertin and Philippe Constant*
}

Institut National de la Recherche Scientifique-Institut Armand-Frappier, Laval, QC, Canada

Edited by:

Claudia Knief, University of Bonn, Germany

\section{Reviewed by:}

Steffen Kolb, University of Bayreuth, Germany

Yin Chen, University of Warwick, UK

\section{*Correspondence:}

Philippe Constant, Laboratory of Trace Gas Biogeochemistry, INRS-Institut Armand-Frappier,

531 Boulevard des Prairies, Laval, QC H7V 1B7, Canada

e-mail:philippe.constant@iaf.inrs.ca
Soil carboxydovore bacteria are the biological sink of atmospheric carbon monoxide (CO). The initial oxidation of $\mathrm{CO}$ is catalyzed by a $\mathrm{CO}$-dehydrogenase $(\mathrm{CODH})$, and the gene $\operatorname{cox} L$ encodes the large subunit of the enzyme. Only a few carboxydovore isolates were shown to oxidize atmospheric $\mathrm{CO}$ and little is known about the potential impact of global change on the ecophysiology of this functional group. The main objective of this study was to assess the impact of land-use and soil properties on coxL gene diversity and identify molecular indicators for the soil uptake of atmospheric $\mathrm{CO}$. Soil samples were collected in three neighboring sites encompassing different land-use types, namely deciduous forest, larch plantation and maize field. CO uptake activity was related to total carbon and nitrogen content in soil, with the highest activity observed in deciduous forest. An extensive coxL database was assembled to optimize a PCR detection assay targeting sequences belonging to functional type I-CODH and hypothetical type II-CODH. Fully replicated $\operatorname{coxL}$ gene libraries unveiled a unique molecular signature in deciduous forest soil, with enrichment of type I sequences. Genetic profiles of larch and maize monocultures were not statistically different and showed higher level of coxL gene richness than deciduous forest. Soil water content and CO uptake activity explained $38 \%$ of the variation of $\operatorname{coxL}$ gene profiles in a canonical ordination analysis, leading to the identification of sequences belonging to the $\delta$-Proteobacteria cluster as indicator for high affinity $\mathrm{CO}$ uptake activity. Enrichment of type I and $\delta$-Proteobacteria cox $L$ sequences in deciduous forest were confirmed by qPCR in an independent soil survey. CO uptake activity in model carboxydovore bacteria suggested that a significant fraction of detected putative high affinity $\mathrm{CO}$ oxidizers were active in soil. Land-use was a driving force separating coxL diversity in deciduous forest from monocultures.

Keywords: trace gas, soil uptake, atmosphere, global change, gas exchanges

\section{INTRODUCTION}

Carbon monoxide (CO) is present at the trace level in the atmosphere, with typical background levels ranging from 1 ppmv in urban areas to $0.1 \mathrm{ppmv}$ in remote locations (Novelli et al., 1998; Chan et al., 2002). A combination of modeling approaches attributed biogenic hydrocarbons and methane oxidation, biomass burning and fossil fuel utilization as the main sources of $\mathrm{CO}$ in the atmosphere, representing $2500 \mathrm{Tg} \mathrm{CO}$ year $^{-1}$ global emissions (Holloway and Levy, 2000). This trace gas has a relatively short atmospheric lifetime of $0.4-2$ months, owing to its strong reactivity toward hydroxyl radicals $(\mathrm{OH} \cdot)$, the cleansing molecules in the atmosphere. Because of this $\mathrm{OH} \cdot-$ mediated reaction, $\mathrm{CO}$ indirectly influences the distribution of methane, and thus is considered as an indirect greenhouse gas (Daniel and Solomon, 1998). The uptake of atmospheric CO, catalyzed by specialized microorganisms thriving in oxic soil, is the most uncertain term of CO budget, representing about $15 \%$ of the global loss of this trace gas in the atmosphere. Despite the fact that industrialization has increased CO global emissions in the last century (Assonov et al., 2007), current CO concentrations are relatively stable in the atmosphere. Long-term time series analysis unveiled slight but significant decreasing trends of $\mathrm{CO}$ concentration in response to reduced industrial and motor vehicle emissions, disturbed by episodic $\mathrm{CO}$ pulses originating from forest fires (Novelli et al., 2003; Chevalier et al., 2008). This delicate balance in the atmospheric burden of $\mathrm{CO}$ largely relies on microbiological and chemical processes responsible for the abatement of global emissions. Resilience, resistance, or vulnerability of the biological sink of $\mathrm{CO}$ to global change, including changes in land-use and climate, must be assessed to predict the fate of atmospheric $\mathrm{CO}$ budget. Identification and characterization of soil CO-oxidizing bacteria are mandatory to achieve this challenging task.

In general, $\mathrm{CO}$ is a highly toxic gas due to its high affinity to metal-containing enzymes involved in respiratory chains. Sophisticated CO-insensitive metabolisms have evolved in bacteria adapted to exploit this trace gas distributed ubiquitously in the environment. CO-oxidizing bacteria possess a $\mathrm{CO}$-dehydrogenase 
$(\mathrm{CODH})$ catalyzing the reaction: $\mathrm{CO}+\mathrm{H}_{2} \mathrm{O} \rightarrow \mathrm{CO}_{2}+2 \mathrm{H}^{+}+$ $2 \mathrm{e}^{-}$. The enzyme is a member of the molybdenum-containing hydroxylases comprising aldehyde oxidoreductase and xanthine dehydrogenase participating in purine nucleotide metabolism (Hille, 2005). In aerobic CO-oxidizing bacteria, $\mathrm{CODH}$ is a dimer of heterotrimers consisting of the small (CoxS), medium (CoxM), and large (CoxL) subunits (Dobbek et al., 2002). The active site embedded in the large subunit comprises a dinuclear molybdenum and copper heterometal cluster unique to CODH. Two physiological groups of aerobic $\mathrm{CO}$-oxidizing bacteria have been identified. Carboxydotrophic bacteria are generally facultative chemolithoautotrophs, using $\mathrm{CO}$ as a sole carbon and energy source if organic substrates are growth limiting (Mörsdorf et al., 1992). These bacteria have a low affinity toward CO and are incapable of scavenging atmospheric CO (Conrad et al., 1981). In contrast, carboxydovore bacteria cannot grow in presence of elevated level of CO. These bacteria exhibit a versatile mixotrophic metabolism, allowing them to grow on mixtures of inorganic and organic substrates (King and Weber, 2007). In soil, carboxydovore bacteria scavenge atmospheric $\mathrm{CO}$ and take advantage of $\mathrm{CO}$ diffusing in soil from nitrogen-fixing nodules as well as chemical degradation of organic matter.

A few high affinity carboxydovore bacteria have been isolated so far and very little is known about the environmental control on their distribution and activity (King and Weber, 2007). Phylogenetic analysis of coxL gene sequences revealed the occurrence of two different groups of $\mathrm{CODH}$, namely the functional type I-CODH and the hypothetical type II-CODH. Type I-CODH are the most extensively studied and are found in the model carboxydotrophic bacterium Oligotropha carboxidovorans as well as carboxidovores such as Stappia and Mycobacterium isolates demonstrating the ability to scavenge atmospheric CO (King, 2003a,b; Weber and King, 2007). Comparatively less is known about the second group, since the occurrence of a functional type II-CODH never has been reported. Distribution of type I- and type II- $\operatorname{coxL}$ sequence has been investigated in the environment. Although both phylogenetic groups are ubiquitous in soil, the environmental control on their distribution remains to be elucidated. The objective of this study is to assess the impact of land-use on carboxydovore activity and diversity. We tested the hypothesis that adjacent sites encompassing different land-use types harbor distinct CO-oxidizing bacterial community structure and density, resulting in a site-specific $\mathrm{CO}$ uptake activity and coxL diversity profile. Soil physicochemical parameters, known to vary within the three ecosystems, such as carbon content and $\mathrm{pH}$, were expected to explain the spatial distribution of this functional group in soil due to the importance of these factors in shaping soil microbial communities structure (Vasileiadis et al., 2013).

\section{MATERIALS AND METHODS SITES AND SAMPLING}

Soil samples were collected at the Verchères Arboretum in St. Amable, (QC, Canada), located about $40 \mathrm{~km}$ from Montreal on the south shore of the St. Lawrence River $\left(45^{\circ} 67^{\prime} \mathrm{N} ; 73^{\circ} 32^{\prime} \mathrm{W}\right)$. The landscape of the sampling site is a mosaic encompassing a broad range of ecosystem types arranged over a relatively small area $\left(<1 \mathrm{~km}^{2}\right)$. Among these ecosystems are tree nurseries (e.g., spruce, larch, pine) established by the ministère des ressources naturelles-Québec (MRNQ) for seed production to support reforestation programs. Fifteen years ago, the MRNQ converted part of the original agricultural area to tree plantations, leaving some parcels for agronomic production as well as unseeded lands that led to the emergence of a natural deciduous forest (MRNQ, pers. Commun.) For the purpose of this study, three adjacent areas with contrasting land-use types were sampled: maize monoculture area (stations A1, A2, A3), hybrid larch (Larix marschlinsii Coaz) plantation established by the MRNQ (stations M1, M2, M3) and the natural deciduous forest (stations F1, F2, F3). Three stations were identified in each ecosystem to collect composite soil samples ( 3 land-use types $\times 3$ stations $=9$ composite samples). Each composite soil sample consisted of six subsamples collected along a 2-m radius traced from a central point. The A-horizon was collected, from the soil surface to a depth of $10 \mathrm{~cm}$ as this zone comprises the highest CO uptake activity (King, 1999b). Surface litter in the forests and debris from the previous crop in the maize sites were removed before sampling. Samples were placed in plastic bags and transferred at $4^{\circ} \mathrm{C}$ within $2-4 \mathrm{~h}$ following their collection in the field. All samples were stored less than 3 months before laboratory analyses. A first soil survey was undertaken in April 2012. Soil of the maize monoculture was bare and unplowed, with a few crop residues remaining on the surface. Samples were used for CO uptake measurements, physicochemical analyses and coxL clone libraries. Sampling sites were visited for a second soil survey in November 2013. In contrast to the first survey, crop residues (i.e., senescent maize) resulting from plowing, were present at the maize monoculture sampling sites. Soil samples collected in 2013 were used for CO uptake and coxL qPCR assays.

\section{SOIL PHYSICOCHEMICAL PROPERTIES}

Soil texture was determined with the hydrometer method and particle size distribution (Table 1) assigned soil samples to the silt loam textural class (Elghamry and Elashkar, 1962). Soil pH was analyzed in soil:water suspensions (1:2) and soil water content was measured using standard gravimetric method. Soil nutrients were analyzed in external service laboratories (INRS-Centre Eau, Terre et Environnement, QC, Canada). Phosphorus and potassium were analyzed by inductively coupled plasma optical emission spectrometry (ICP-AES) after acid extraction, while total carbon and total nitrogen soil content were determined using an elemental combustion system.

\section{MICROORGANISMS}

Mycobacterium smegmatis (DSMZ 43756) and Stappia kahanamokuae (DSMZ 18969) were purchased at the Leibniz Institute DSMZ - German Collection of Microorganisms and Cell Cultures, while Burkholderia xenovorans LB400 was kindly provided by the laboratory of Dr. Michel Sylvestre (INRS-Institut Armand-Frappier). M. smegmatis and B. xenovorans were grown in PYE broth (Kimble et al., 1995) and Bacto Marine Broth (Difco 2216) was used for the growth of $S$. kahanamokuae. Cultures were incubated at $30^{\circ} \mathrm{C}$ under $200 \mathrm{rpm}$ agitation. Triplicate cultures dedicated to CO uptake measurements $(20 \mathrm{ml})$ were incubated in gastight $500 \mathrm{ml}$ Wheaton ${ }^{\circledR}$ glass bottles equipped with a rubber 
septum cap. Defined volume of CO gas mixture $(508 \pm 10$ ppmv CO, GST-Welco, PA, USA) was injected to get $\sim 3$ ppmv in the static headspace after inoculation. Headspace samples were collected during the incubation period to measure $\mathrm{CO}$ oxidation activity (see below). Independent triplicate cultures were also prepared in parallel to monitor bacterial growth by optical density readings. The biomass of stationary phase cultures was quantified by agar plate enumeration using PYE and Bacto Marine agar media.

\section{CO UPTAKE ACTIVITY}

CO uptake activity was measured using either soil samples $\left[\sim 50 \mathrm{~g}_{\text {(drybasis) }}\right]$ or bacterial cultures. Soil samples were placed into $500 \mathrm{ml}$ gastight Wheaton ${ }^{\circledR}$ glass bottles with rubber septum caps. Diffusion limitation of the activity was negligible since preliminary experiments showed proportional CO uptake activity as a function of the amount of soil in the assay using 25, 50, 75 , and $100 \mathrm{~g}$ soil samples (data not shown). Bottles containing soil samples were tightly closed and CO gas mixture (508 \pm 10 ppmv CO GST-Welco, PA, USA) was injected to get $\sim 1$ ppmv initial concentration in the static headspace. Decrease of the CO mixing ratio was monitored as a function of time by analyzing aliquots $(10 \mathrm{ml})$ of the headspace air in a Trace Analytical Reduced Gas Analyzer (ta3000R, Ametek Process Instruments ${ }^{\circledR}$, DE, USA) as previously described (King, 1999a). Apparent first order CO uptake rate constants were obtained by integrating the logarithmic decrease of headspace CO mixing ratio. Measurements were performed using biologically independent triplicates and at least five $\mathrm{CO}$ concentration points were used for data integration. Experiments involving soil samples were accomplished over 20-60 min, depending on microbial activity. CO uptake activity in bacterial cultures was measured over a 7-day period. Cell-specific CO oxidation rate ( $\mathrm{pmol} \mathrm{cfu} \mathrm{ch}^{-1} \mathrm{~h}^{-1}$ ) was calculated by normalizing the activity to biomass as determined by agar plate enumeration. Reproducibility of the CO analyses was assessed before each set of measurements by repeated analysis of certified CO standard gas $(2.05 \pm 0.10$ ppmv, GST-Welco, PA, USA), and standard deviations were lower than 5\%. No significant CO uptake was observed for blank experiments involving sterile media or empty glass bottles. Considering the occurrence of simultaneous CO production and consumption activities in nature and their dependence on temperature, moisture and solar radiations, rates of $\mathrm{CO}$ oxidation in soil presented in this study must be considered as potential CO uptake activities.

\section{coxL PHYLOGENETIC ANALYSIS AND PCR DETECTION ASSAYS}

Sequences similar to coxL in Mycobacterium smegmatis (type I-CODH) and Burkholderia xenovorans (type I- and type II-CODH) were retrieved from the National Center for Biotechnology Information (NCBI) database (http://www.ncbi. nlm.nih.gov/) using the protein Basic Local Alignment Search Tool (Altschul et al., 1990). Nucleic acid sequences were imported in the software Mega (Tamura et al., 2007), translated in silico, and the amino acid sequences were aligned using Muscle (Edgar, 2004). Alignments were manually refined and functional amino acid sequence motifs of the active site distinguishing $\operatorname{coxL}$ sequences belonging to type I-CODH (AYXCSFR) from 
type II-CODH (AYRGAGR) were examined in order to validate specificity of the retrieved sequences (King and Weber, 2007). Phylogenetic tree of amino acid sequences translated from cox $L$ gene sequences was constructed with maximum-likelihood algorithm. The alignment was used to identify consensus regions to design coxL-specific oligonucleotides. Three sets of degenerated primers were developed to detect and quantify presumptive CO-oxidizers in soil, so-called universal-coxL, type I-coxL, and $\delta$-Proteobacteria-coxL assays (Table 2 ).

$16 \mathrm{~S}$ rRNA gene sequences were retrieved from the genome of 102 presumptive CO-oxidizing bacteria identified in the coxL database (Table S1). 16S sequences were classified into two databases: type I-coxL and type II-coxL groups, as a function of $\operatorname{coxL}$ gene harbored by the bacteria, and then aligned. Pairwise difference $(D)$ matrices were computed to obtain the similarity scores $S(S=1-D)$ of all possible combinations of $16 \mathrm{~S}$ rRNA and $\operatorname{cox} L$ gene sequences for both databases. Comparisons between the percentages of similarity of all $\operatorname{cox} L$ pairs and the sequence similarities of the $16 \mathrm{~S}$ rRNA genes of the same bacteria were performed by regression analysis $(n=820$ and $n=1830$ for type I and type II databases, respectively). This pairwise similarity score analysis has recently been utilized to establish a similarity score threshold value for nitrate/nitrous oxide reductases (Palmer et al., 2009), particulate methane monooxygenase (Degelmann et al., 2010), and hydrogenase (Constant et al., 2011b) gene sequences at the species level.

\section{DNA EXTRACTION AND UNIVERSAL-coxL PCR}

Soil DNA was extracted from an exact amount of soil ( $\sim 500 \mathrm{mg})$ using the FastDNA Spin Kit (MP Biomedicals ${ }^{\circledR}, \mathrm{OH}$, USA) for soil according to the manufacturers protocol. DNA was eluted in $50 \mu \mathrm{L}$ nuclease-free water. DNA samples were diluted (1:10, 1:100, and 1:500) before the PCR due to residual humic acids inhibition. All PCR mixtures consisted of $1 \times$ reaction buffer $\left(15 \mathrm{mM} \mathrm{MgCl}_{2}\right.$ ), $0.2 \mathrm{mM}$ deoxynucleotide triphosphates, $10 \mu \mathrm{M}$ of each primer (Table 2), $0.8 \mathrm{mg} \mathrm{ml}^{-1}$ bovine serum albumin, 1.25 U Fast-Taq polymerase (Feldan ${ }^{\circledR}, \mathrm{QC}$, Canada), $2 \mu$ l diluted

Table 2 | List of the primers designed in this study.

\begin{tabular}{llc}
\hline Assays (coxL) & Primers & $\begin{array}{c}\text { PCR-amplified } \\
\text { fragment size } \\
\text { (bp) }\end{array}$ \\
\hline Universal (PCR) & $\begin{array}{l}\text { uni820-forward: } \\
\text { 5'-GGBGGBGGYTTYGGCWMSAA-3' } \\
\text { uni1611-reverse: }\end{array}$ & 800 \\
& 5'-GTBKCRTGNCCCTGNCC-3' & \\
\hline Type I (qPCR) & $\begin{array}{l}\text { type l-1288-forward: } \\
\text { 5'-TSKKYACSGGCWSSTA-3' }\end{array}$ & \\
& $\begin{array}{l}\text { type I-1540-reverse: } \\
\text { 5'-TAYGAYWSSGGYRAYTA-3' }\end{array}$ & \\
\hline$\delta$-Proteobacteria & D967-forward: \\
(qPCR) & 5'-TTCTWCKCYGAYGCVCARCC-3' & \\
& D1285-reverse: & 291 \\
& 5'-CBGAGTCGGDSASGAADCC-3' & \\
&
\end{tabular}

DNA and nuclease-free water to obtain a final volume of $50 \mu \mathrm{L}$. A touchdown PCR protocol was used for the universal-coxL assay as follow: $95^{\circ} \mathrm{C}$ for $5 \mathrm{~min}, 16$ cycles of "touchdown steps" denaturing at $95^{\circ} \mathrm{C}$ for $20 \mathrm{~s}$, annealing temperature starting at $65^{\circ} \mathrm{C}$ decreasing $0.5^{\circ} \mathrm{C}$ in every cycle to reach a temperature of $55^{\circ}(40 \mathrm{~s}$ at each cycle), and a elongation step of $72^{\circ} \mathrm{C}$ for $45 \mathrm{~s}$, completed with a final set of 19 regular PCR cycles of $95^{\circ} \mathrm{C}$ for $20 \mathrm{~s}, 55^{\circ} \mathrm{C}$ for $40 \mathrm{~s}$ and $72^{\circ} \mathrm{C}$ during $45 \mathrm{~s}$ with a final extension of $72^{\circ} \mathrm{C}$ for $5 \mathrm{~min}$.

\section{coxL GENE LIBRARIES}

One coxL gene library was derived from each sampling station, resulting in nine fully replicated libraries. Partial coxL gene sequences were PCR-amplified using the universal-coxL assay and cloned in pGEM-T ${ }^{\circledR}$ Easy Vector cloning Kit (Promega, WI, USA). Recombinant colonies were selected, plasmid DNA extracted following standard procedure (Sambrook and Russell, 2001) and coxL inserts were PCR-amplified and sequenced using the Sanger's Method (Génome Québec Innovation Centre, McGill University, QC, Canada). In total, 279 clones were obtained. Clone sequences were aligned and in silico translated to verify the canonical signature of the active site characterizing type I and type II coxL sequences. The OTU representative sequences (0.90 similarity cut-off) obtained using the universal-coxL assay were deposited in the GenBank database with accession numbers KJ395119 to KJ395310. UniFrac distance matrix, reflecting the pairwise phylogenetic distance between the sequences retrieved from each sampling site was calculated to verify if land-use types have significantly different microbial communities (Lozupone and Knight, 2005).

\section{TYPE I- AND $\delta$-PROTEOBACTERIA-coxL qPCR ASSAYS}

Type I- and $\delta$-Proteobacteria-coxL genes were PCR-amplified using the universal-coxL assay and plasmid DNA of clone 55M3 (accession number KJ395179) and genomic DNA of Haliangium ochraceum DSM 14365 as matrices, respectively. PCR products were concentrated and purified with standard commercial kits (E.Z.N.A. Cycle Pure Kit, Omega Bio-Tek ${ }^{\circledR}$, GA, USA). Purified DNA was quantified with fluorescent DNA-binding dye (Quantifluor dsDNA, Promega, WI, USA). Standard curves for type I- and $\delta$-Proteobacteria-coxL qPCR assays were obtained using serial dilutions of quantified DNA $\left(10^{1}-10^{9}\right.$ copies $\left.\mu l^{-1}\right)$. Reactions contained $1 \times$ Perfecta SYBR Green Fast Mix reaction buffer (Quanta Biosciences ${ }^{\circledR}, \mathrm{MD}$, USA), $15 \mu \mathrm{M}$ of each primer (Table 2), $0.3 \mathrm{mg} \mathrm{ml}^{-1}$ bovine serum albumin, $5 \mu \mathrm{L}$ diluted DNA (1:500) and nuclease-free water to obtain a final volume of $20 \mu \mathrm{L}$. Preliminary experiments with internal standard DNA spiked in soil DNA extracts (Deer et al., 2010; Decoste et al., 2011) were conducted and showed undistinguishable qPCR-signal recovery between the samples using 1:500 DNA dilutions. Furthermore, qPCR results from 1:500 to 1:1000 dilutions were undistinguishable, providing no significant incidence of PCR inhibitors on coxL abundance data (data not shown). Reactions were performed in the Rotor Gene 6000 (Corbett Life Science ${ }^{\circledR}$, NSW, Australia) with the following conditions: $94^{\circ} \mathrm{C}$ for $5 \mathrm{~min}, 35$ cycles of $94^{\circ} \mathrm{C}$ for $30 \mathrm{~s}, 51^{\circ} \mathrm{C}$ (Type I-coxL) or $56^{\circ} \mathrm{C}(\delta$-Proteobacteria-cox $L$ ) for $30 \mathrm{~s}, 68^{\circ} \mathrm{C}$ for $20 \mathrm{~s}$ (Type I-coxL) or $15 \mathrm{~s}$ ( $\delta$-Proteobacteria-cox $L$ ) with fluorescence acquisition following each $68^{\circ} \mathrm{C}$ step and a 
melting cycle with a ramp from 75 to $99^{\circ} \mathrm{C}$, rising $0.2^{\circ} \mathrm{C}$ every $5 \mathrm{~s}$. Replicate calibration curves were performed to verify the accuracy of the qPCR resulting in an efficiency of $0.70\left(R^{2}=0.98\right)$ and $0.73\left(R^{2}=0.96\right)$ for type I- and $\delta$-Proteobacteria-cox $L$ assays, respectively. Type I- and $\delta$-Proteobacteria-cox $L$ gene libraries were also performed to confirm the specificity of the assays. The resulting type I- and $\delta$-Proteobacteria-coxL sequences with more than $200 \mathrm{pb}$ length have been deposited in the GenBank database with accession numbers KJ567007 to KJ567022 and KJ567023 to KJ567040, respectively.

\section{STATISTICAL ANALYSIS}

Gene libraries were normalized to the sequencing effort of the smallest coxL library to avoid biases in comparative analyses introduced by the sampling depth. Using the software Mothur (Schloss et al., 2009), $24 \operatorname{coxL}$ sequences were randomly selected from the nine libraries. The resulting sequences were grouped into operational taxonomic units (OTU) defined by a similarity level of 0.90 . These files were used for diversity index calculation and statistical analysis. Redundancy analysis (RDA) was computed using the Vegan package (Dixon, 2003) implemented in R (R Development Core Team, 2008) according to the comprehensive procedure described by Borcard et al. (2011). RDA is a constrained analysis, used to extract structures of an observational dataset related to explanatory variables. In this study, RDA was considered to identify environmental variables influencing the structure of $\operatorname{coxL}$ gene profile in soil, in addition to highlight $\operatorname{coxL}$ sequences whose presence is related to elevated $\mathrm{CO}$ soil uptake activity. This test was preferred from canonical analysis due to the occurrence of several null values in the coxL data matrix. Soil variables (e.g., $\mathrm{pH}$, carbon, nitrogen, water content, $\mathrm{CO}$ uptake activity) were standardized by subtracting individual values by the average and dividing them by the standard deviation. This transformation procedure resulted in centered data or $z$-scores, generating variables characterized by an average of zero and a standard deviation of 1 . The Hellinger transformation was applied to coxL OTU frequency distribution before computing the distance matrix to avoid unduly relationships between explanatory variables and coxL composition supported by the high weight of rare species (Legendre and Gallagher, 2001). The most parsimonious constrained model to explain coxL composition was obtained by forward selection of the environmental variables (Blanchet et al., 2008) and permutation tests $(n=1000)$ were performed to assess the significance of the RDA. Pearson correlation analyses were conducted to identify environmental variables related to soil $\mathrm{CO}$ uptake activity. Analysis of variance with Bonferroni post-hoc statistical test was performed to compare CO uptake activity and abundance of coxL genes between the three land-use types (SigmaPlot $12^{\circledR}$, Systat Software Inc., CA, USA).

\section{RESULTS}

\section{SOIL PROPERTIES AND CO UPTAKE ACTIVITY}

Triplicate composite soil samples (A-horizon) were collected in April 2012 to relate CO uptake activity to soil physicochemical properties and coxL diversity profiles. The highest carbon and nitrogen contents were detected in deciduous forest soil, while maize monoculture showed the maximum levels of potassium and phosphorus (Table 1). Distribution of the measured variables showed some level of co-linearity. Indeed, soil water content was positively related to $\mathrm{K}, \mathrm{P}$, and $\mathrm{pH}$ (Pearson correlation, $P<$ $0.05)$ and inversely related to total carbon and nitrogen content (Pearson correlation, $P<0.01)$. Variations in soil physicochemical properties resulted in a broad range of $\mathrm{CO}$ uptake activities, from $45 \mathrm{pmol} \mathrm{g}_{(\mathrm{dw})}^{-1} \mathrm{~h}^{-1}$ in larch plantation (station M2) to $3243 \mathrm{pmol} \mathrm{g}_{(\mathrm{dw})}^{-1} \mathrm{~h}^{-1}$ in deciduous forest (station F3). The activity was positively correlated to carbon and nitrogen content in soil (Pearson correlation, $P<0.01$ ), whereas no significant relationship was observed with the other variables. In accordance with total carbon and nitrogen profiles, $\mathrm{CO}$ uptake activity observed in deciduous forest soil was greater than in maize and larch plantations (ANOVA, $P<0.05$ ), while soil samples collected from these two sites could not be distinguished based on their $\mathrm{CO}$ uptake activity. CO compensation concentration, reached when $\mathrm{CO}$ production and consumption rates are equivalent, was at the detection limit of the gas chromatographic system for the three ecosystem types (i.e., $<25 \mathrm{ppbv}$ ), impairing estimation of the gross production and consumption rates of CO (Conrad, 1994).

\section{DETECTION OF $\operatorname{coxL}$ GENOTYPES}

An extensive phylogenetic analysis of $\operatorname{cox} L$ gene sequences was essential to get fundamental information regarding the evolution of functional type I-CODH and hypothetical type II$\mathrm{CODH}$, to optimize the universal-coxL PCR detection assay as well as to interpret gene libraries data. Putative coxL gene sequences were obtained from genome sequencing projects and $\mathrm{CO}$-oxidizing bacteria exhibiting high affinity $\mathrm{CO}$ uptake activity (Figure 1). A parsimonious phylogenetic reconstruction of the type I-CODH group was obtained, while type II-coxL sequences were distributed in several clusters for which topology was poorly supported by bootstrap analysis (Figure 1A). Inspection of the conserved amino acid signature of the active site unveiled the occurrence of atypical motif in Saccharomonospora viridis and Streptospotangium roseum (Figure 1A). The PYRGAGR signature observed in these bacteria diverged from the canonical AYRGAGR motif of type II sequences. Pairwise sequence similarity scores of $16 \mathrm{~S}$ rRNA and $\operatorname{coxL}$ genes were calculated to test whether standardization of the classification of coxL sequences is possible under "species-level" OTU and to assign environmental coxL sequences to taxonomic groups in phylogenetic analyses. The pairwise sequence similarity scores were correlated in bacteria possessing type I-coxL sequence, where the linear regression model $(n=820, P<0.001)$ predicts a species-level similarity score threshold of $0.89 \pm 0.04$ (Figure 2A). For type II sequences, the regression model $(n=$ 1830, $P<0.001)$ was associated to a species-level similarity score threshold of $1 \pm 0.07$ (Figure 2B), providing indication for different evolution histories for both types of $\mathrm{CODH}$. Evidence of lateral transfer was noticed for type II-CODH. For instance, type II-coxL sequence detected in the aerobic hyperthermophilic Crenarchaeota Aeropyrum pernix was affiliated with that of a member of the Chloroflexi phylum (Sphaerobacter thermophilus), supporting potential lateral gene transfer event in the Archaea (Figure 1A). The extensive $\operatorname{coxL}$ database was 
utilized to optimize previous universal coxL PCR detection assay (Table S2).

Genomic DNA was extracted from nine composite soil samples and $\operatorname{cox} L$ genes were PCR-amplified, cloned and sequenced.
In total, 279 clones were derived from the maize (73), larch (93), and deciduous forest (113) samples. Sequences were classified into 192 different OTU using an arbitrary cut-off of 10\% difference to accommodate both type I- and type II-coxL sequences.

A

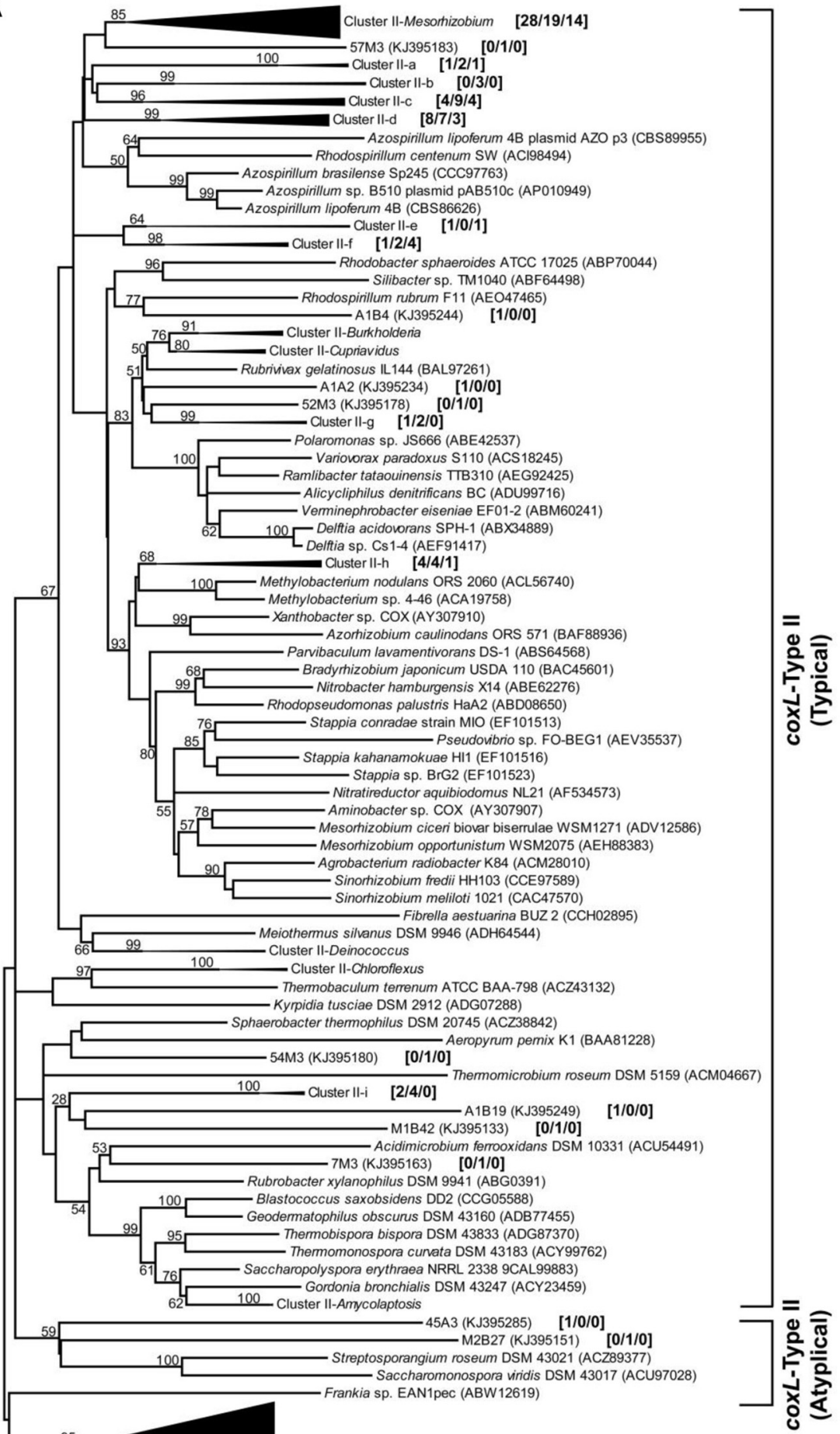

Type I $[19 / 35 / 85]$ 


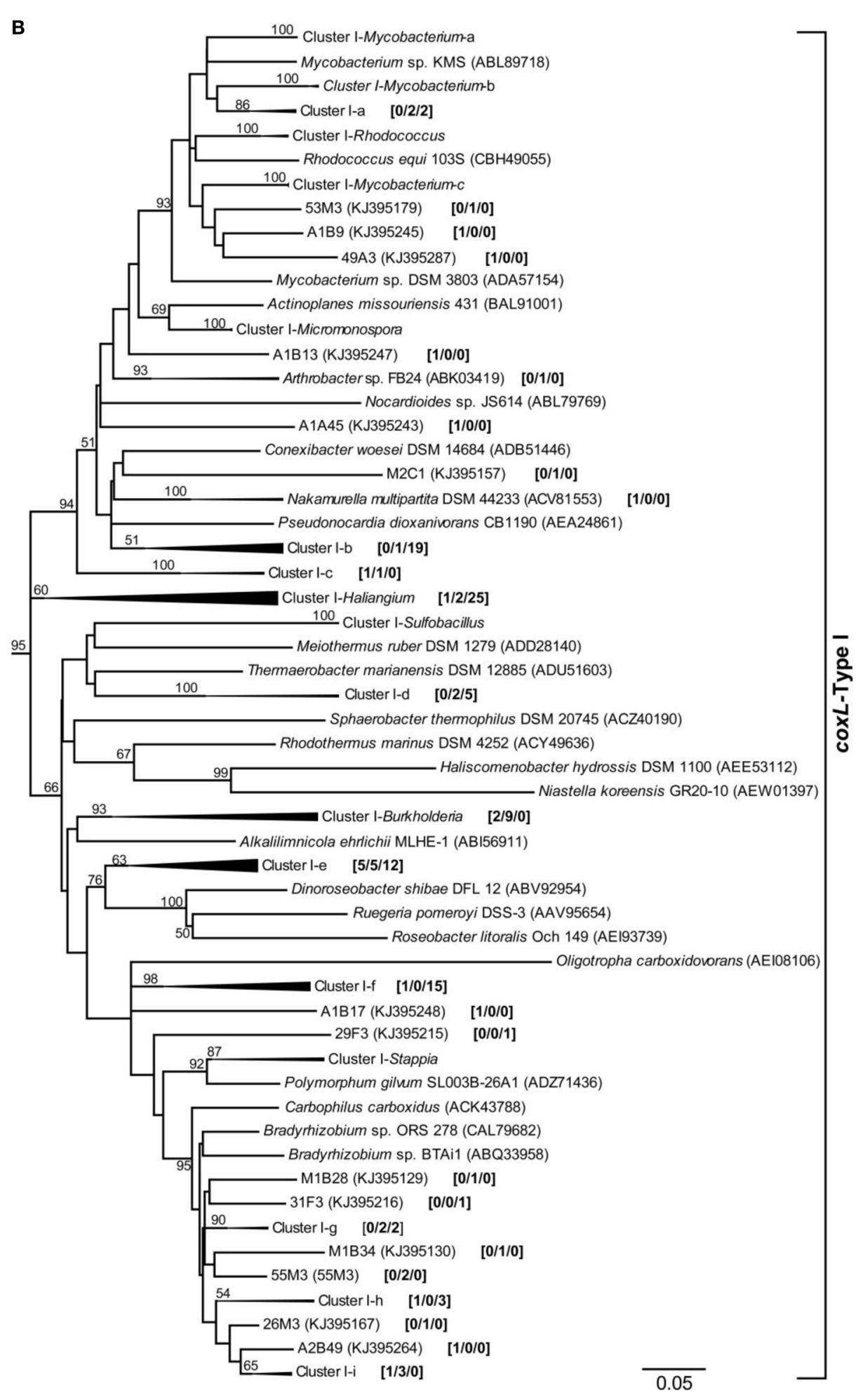

FIGURE 1 | Phylogenetic analysis of coxL-inferred amino acid sequences (313 residues) by the maximum-likelihood algorithm (model WAG+G). Global analysis including both type I- and type II-coxL sequences is shown (A) with a detailed view of coxL-type I phylogenetic group (B). The analysis included sequences retrieved from public database along with the 192 OTUs identified in this study. The numbers in brackets show the number of coxL sequences from the nine clone libraries belonging to individual OTUs and clusters [maize/larch/deciduous]. The percentage of replicated trees in which the associated CoxL sequences clustered together in the bootstrap test (1000 replicates) are shown for nodes supported by $\geq 50 \%$ of the replicates. Prefixes of OTUs encompassing type I- and type II-coxL indicate land-use type as follow: $A$, maize monoculture; $M$, larch monoculture; and $F$, deciduous forest. Scale $=$ number of substitutions per site. 

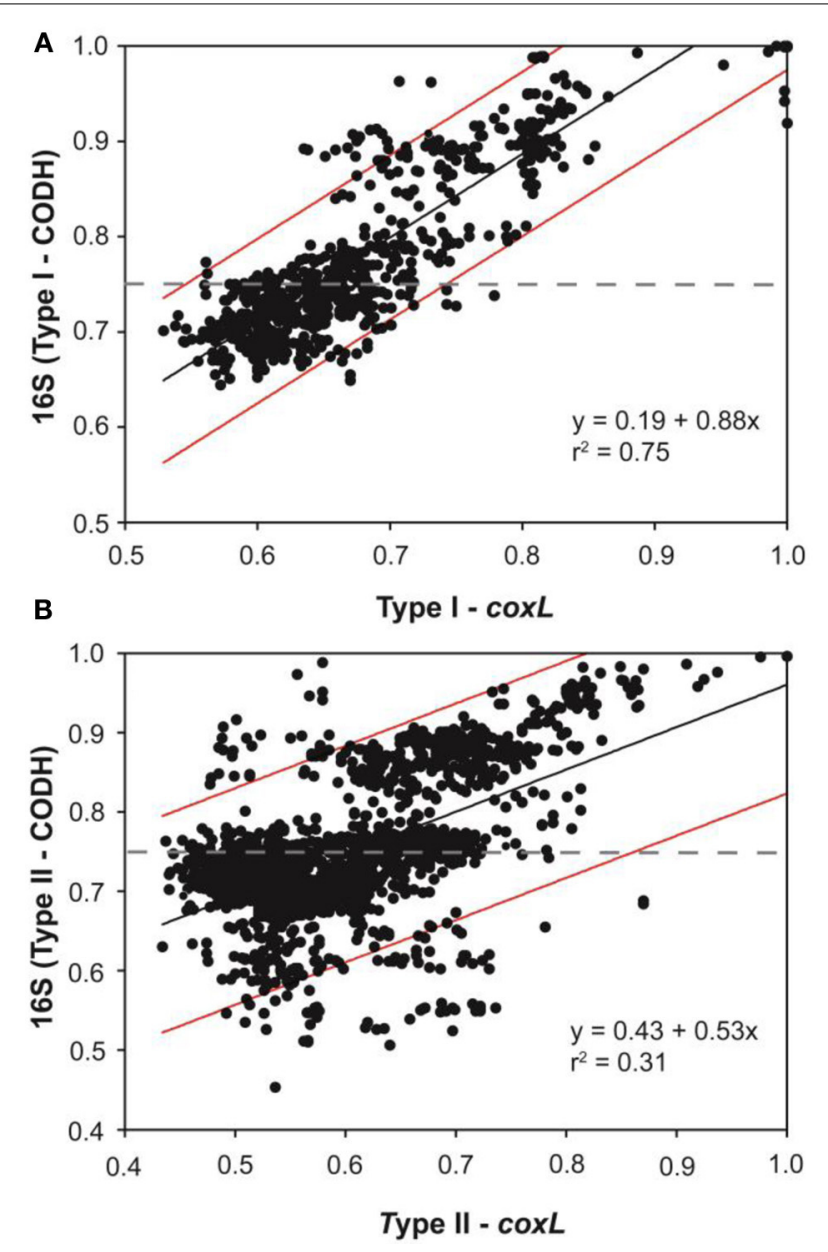

FIGURE 2 | Correlation between the pairwise sequence similarity scores of coxL and the 16S rRNA gene in presumptive CO-oxidizing bacteria belonging to (A) type I-CODH and (B) type II-CODH. The black line represents the linear regression and red lines delineate the prediction interval of the model for the $95 \%$ confidence level.

According to a rarefaction analysis, sampling effort was insufficient to cover the whole diversity of presumptive CO-oxidizing bacteria communities (data not shown). Comparison of the gene libraries thus are representative of the dominant members of this functional group in soil. Diversity metrics indicate lower richness of $\operatorname{coxL}$ sequences sampled in deciduous forest soil than the monocultures (Table 1). The lower value of the Simpson index in deciduous forest reflects dominance of the sampled community by a small number of OTU. UniFrac analysis of the nine coxL gene libraries was in accordance with the diversity metrics. Composition of deciduous forest $\operatorname{cox} L$ gene libraries differed significantly from maize and larch monocultures, while conversion of the agricultural field to larch monoculture 15 years ago did not influence the composition of dominant presumptive COoxidizing bacteria (Figure 3 ). The relative abundance of clones belonging to types I and II varied as a function of land-use type (Figure 4A). Type I-coxL sequences dominated deciduous forest soil, while maize and larch plantations displayed higher

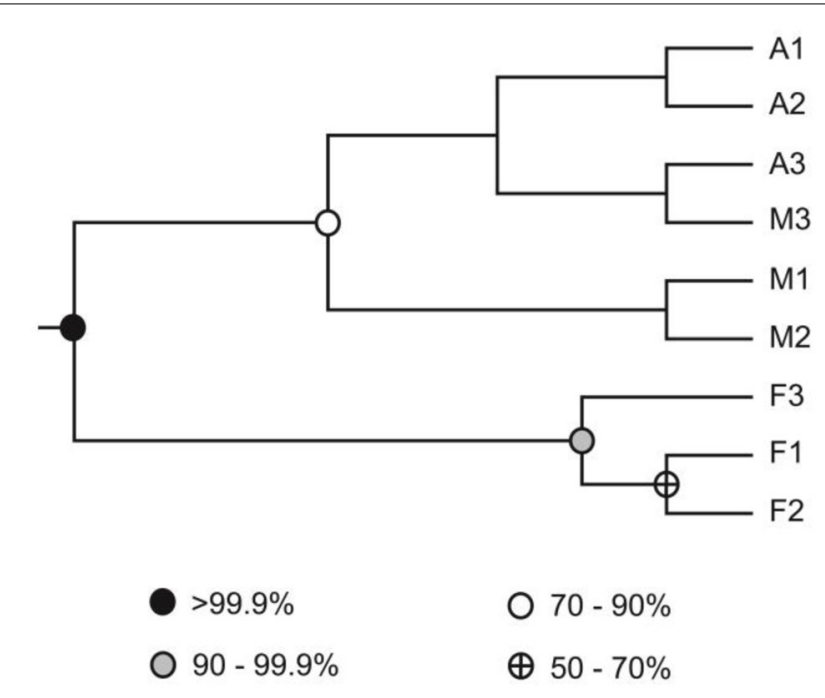

FIGURE 3 | UPGMA dendrogram of soil samples collected in deciduous forest (stations F1, F2, F3), maize monoculture (stations A1, A2, A3), and larch plantation (stations M1, M2, M3). The UPGMA was derived from the UniFrac distance matrix, reflecting the pairwise phylogenetic distance between the sequences retrieved from each sampling station. Nodes are filled as a function of the frequency at which they were found in Jackknife procedure keeping $75 \%$ sequences for the analysis.

proportion of type II. Clone sequences belonging to type II were phylogenetically-distant from cultured representative bacteria. With the exception of the OTU A2B46, affiliated to coxL sequence from Mesorhizobium loti (73\% similarity score, implying both sequences are derived from bacteria that could belong to two different phyla; Figure 2B), no type II sequence related to clusters comprising known CO-oxidizing bacteria was detected (Figure 1A). Phylotypes affiliated to the atypical coxL sequence of $S$. viridis and S. roseum were detected in the three ecosystem types, representing $0.7 \%$ of the analyzed clones. Most of the clones encompassing type I-coxL were comprised in Actinobacteria (16\%), $\alpha$-Proteobacteria (14\%), and $\delta$-Proteobacteria (10\%) clusters. The proportion of clone sequences related to these phyla varied as a function of land-use type. For instance, $27 \%$ type I sequences detected in deciduous forest encompassed the $\delta$ Proteobacteria cluster, while this group represented 6 and $10 \%$ in maize and larch monocultures (Figure 4B).

\section{RELATIONSHIP BETWEEN coxL GENE SEQUENCES AND ENVIRONMENTAL VARIABLES}

A RDA was performed to infer the relationship of coxL gene sequences with environmental variables (Figure 5). The most parsimonious model to explain variation of $\operatorname{coxL}$ sequences included soil CO uptake activity and water content. The other variables being redundant to $\mathrm{CO}$ uptake and soil moisture, their addition in the analysis increased the variance inflation factor unduly and they were therefore ignored in the analysis. The first two canonical axes explained $38 \%$ of the total variance of $\operatorname{cox} L$ OTU frequency distribution. Significance of the RDA was confirmed with 1000 permutations of $\operatorname{cox} L$ data matrix $(P=0.003)$. Soil water content played an important role for the dispersion 

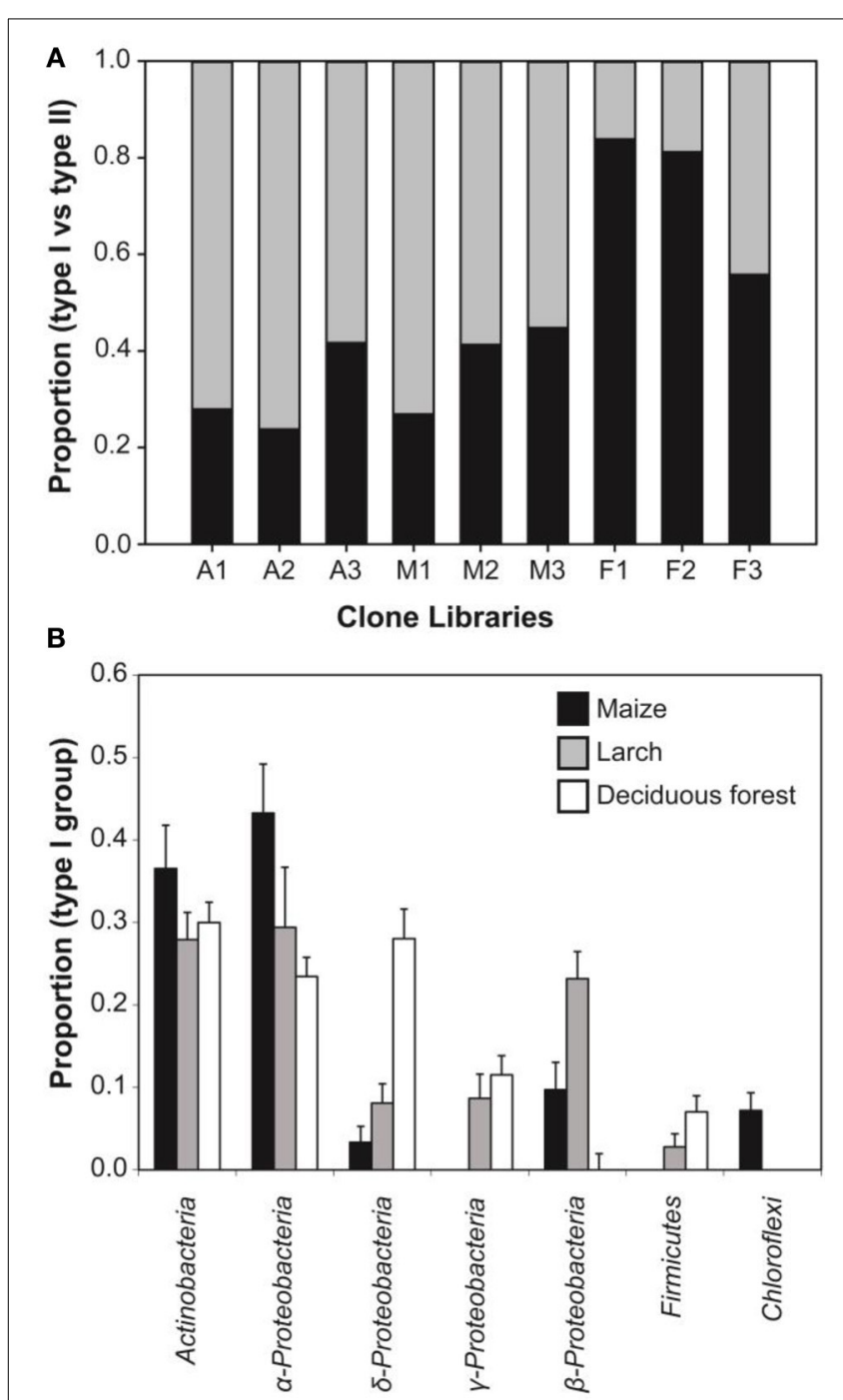

FIGURE 4 | (A) Relative abundance of $\operatorname{coxL}$ clone sequences belonging to type I- (black) and type II-CODH (gray) groups in the nine clone libraries. (B) Percent composition (average \pm standard error of three replicated clone libraries) of bacterial phyla represented by type $1-\operatorname{cox} L$ sequences detected in the three different ecosystems.

of the samples along the first axis, while CO uptake activity discriminated the samples along the second. According to UniFrac analysis, axes clearly separated samples collected in deciduous forest from those originating from both monocultures (Figure 5). The occurrence of 12 OTU was related to higher CO uptake activities. Among them, 10 encompassed type I phylogenetic group (89F3, F187, 3F3 F2A71, M2C2, M1A14, F1A13, F2B13, F171, F2A72), while 2 belonged to type II (32F3, F174). Combined with the higher relative abundance of type I sequences detected in deciduous forest, this observation led us to consider that type IcoxL might be a better indicator of CO uptake activity in soil than type II sequences. OTUs $89 \mathrm{~F} 3$ and F187 were related to deciduous forest samples characterized with the highest $\mathrm{CO}$ uptake activity (Figure 5). These sequences encompass the $\delta$-Proteobacteria cluster, suggesting the relevance of this type I-coxL subgroup to

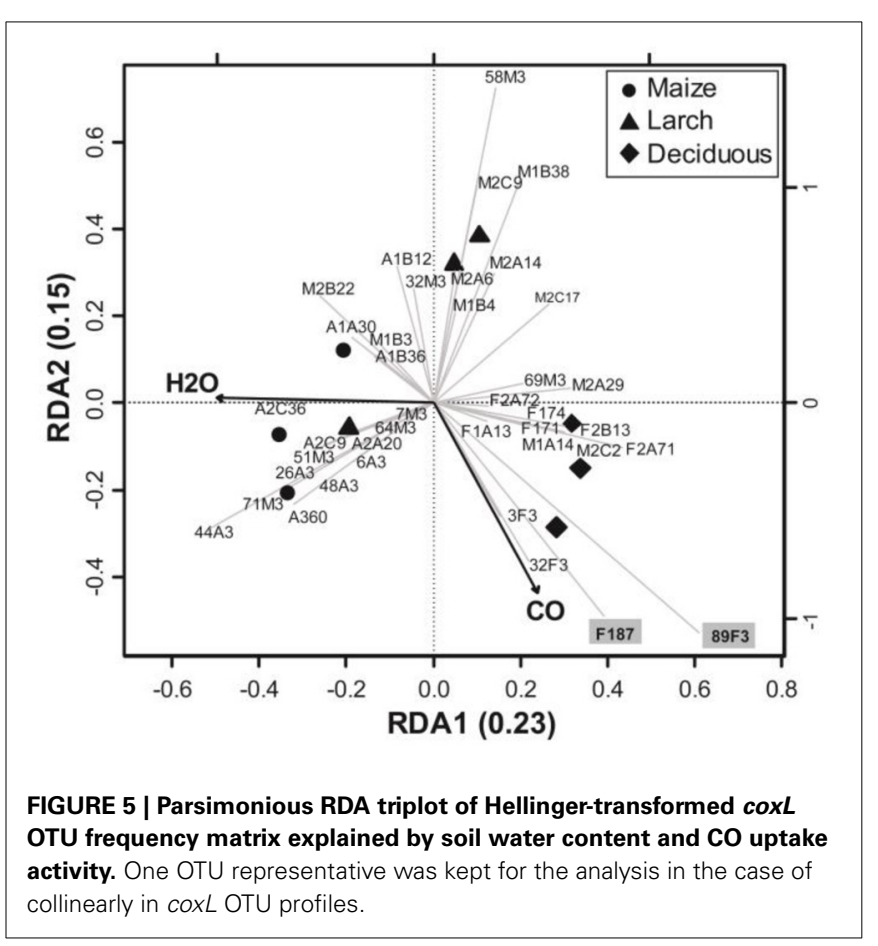

predict $\mathrm{CO}$ oxidation activity in the soil samples. The obligate halophile myxobacterium Haliangium ochraceum isolated from coastal seaweed (Fudou et al., 2002) was the sole cultivated representative of the $\delta$-Proteobacteria cluster, with no report on its $\mathrm{CO}$ uptake activity. We tested the $\mathrm{CO}$ uptake activity of $\mathrm{H}$. ochraceum and confirmed its capability to scavenge atmospheric CO (Figure $\mathrm{S} 1)$. This is the first demonstration of $\mathrm{CO}$ oxidation activity in the $\delta$-Proteobacteria class.

\section{LINKING CO UPTAKE ACTIVITY TO THE ABUNDANCE OF coxL SEOUENCES AND THEORETICAL POPULATIONS OF CARBOXYDOVORES BACTERIA IN SOIL}

Gene libraries suggested that distribution of $\operatorname{coxL}$ sequences belonging to type I or the $\delta$-Proteobacteria cluster reflect $\mathrm{CO}$ soil uptake activity. The analysis was however limited by insufficient sampling effort to cover the whole diversity of coxL sequences in soil as well as PCR and cloning bias. In order to challenge the results of clone libraries, the three sampling sites were visited for a second soil survey in 2013. CO uptake activity was measured and showed the same trend than the 2012 soil survey, with higher oxidation rates in deciduous forest than in monocultures, and total DNA was extracted for qPCR analyses. Degenerated oligonucleotides were designed to quantify $\operatorname{cox} L$ sequences belonging to type I group and $\delta$-Proteobacteria subgroup. Optimization of a broad assay, specific type I-coxL sequences derived from public database and clone sequences obtained in this study was unsuccessful due to no or unspecific amplification signals induced by consensus degenerated primers (data not shown). As an alternative, oligonucleotides were designed based on the clone sequences only. Specificity of the assays was confirmed by $\operatorname{cox} L$ gene libraries (23 clones per 
assay) with 13 and $0 \%$ unspecific sequences for type I and $\delta$ Proteobacteria, respectively. The abundance of type I-coxL varied between $10^{9}$ and $10^{10}$ genes $\mathrm{g}_{(\mathrm{dw})}^{-1}$ in maize and larch monocultures and $10^{10}-10^{11}$ genes $\mathrm{g}_{(\mathrm{dw})}^{-1}$ in deciduous forest (Figure 6A). A similar trend was observed for the $\delta$-Proteobacteria subgroup with an average of $10^{9}$ and $10^{11}$ genes $\mathrm{g}_{(\mathrm{dw})}^{-1}$ for monocultures and deciduous forest, respectively, (Figure 6A). According to $\operatorname{cox} L$ gene libraries, type I-coxL sequences were more abundant in deciduous forest soil than both monocultures $(P=$ $0.004)$. The abundance of $\delta$-Proteobacteria $\operatorname{cox} L$ sequences and the relative proportion of this group was significantly higher in deciduous forest than maize monoculture $(P=0.01)$, while maize and larch monocultures pair as well as larch plantation and deciduous forest pair could not be distinguished based on the abundance of $\delta$-Proteobacteria $\operatorname{cox} L$ sequences. Linear regression analyses showed that abundance of both $\operatorname{coxL}$ subgroups, as estimated by qPCR, was proportional to $\mathrm{CO}$ oxidation activity in soil $(P<0.003)$, but the relationships were largely driven by the contrasting properties of deciduous forest samples (Figure 7).

\section{THEORETICAL POPULATIONS OF CARBOXYDOVORE BACTERIA IN SOIL}

Although differences in the efficiency of the qPCR reaction between standard and environmental DNA templates are expected due to the utilization of degenerated primers, the absolute quantification method remains a standard choice in environmental microbiology (Brankatschk et al., 2012). In order to verify the reliability of the qPCR estimates, three carboxydovore bacteria known to oxidize atmospheric $\mathrm{CO}$ and available in public microorganism culture collections were selected and characterized in term of cell-specific $\mathrm{CO}$ uptake activity. CO oxidation activity was detected at the onset of the stationary phase of the strains demonstrating a broad range in specific activities, from 29 to $2171 \mathrm{zmol} \mathrm{cfu}^{-1} \mathrm{~h}^{-1}$ (Figure 6B). This range in specific activities was used to calculate theoretical populations $[N$; cell $\left.\mathrm{g}_{(\mathrm{dw})}^{-1}\right]$ of metabolically active carboxydovore bacteria necessary to explain the CO uptake activity measured in the second soil survey (Equation 1):

$$
N=\frac{C O_{\text {Soil }}}{C O_{\text {Bacteria }}}
$$

where $\mathrm{CO}_{\text {Soil }}$ is the $\mathrm{CO}$ uptake activity measured in soil [pmol $\mathrm{g}_{(\mathrm{dw})}^{-1} \mathrm{~h}^{-1}$ ] and $\mathrm{CO}_{\text {Bacteria }}$ is the $\mathrm{CO}$ oxidation rate in carboxydovore bacteria ( $\mathrm{pmol} \mathrm{cfu}^{-1} \mathrm{~h}^{-1}$; $\mathrm{cfu}=$ colony forming unit). The lowest and highest cell-specific $\mathrm{CO}$ oxidation activities $\left(\mathrm{CO}_{\text {Bacteria }}\right)$ measured in B. xenovorans and M. smegmatis (Figure 6B) were utilized to calculate the upper and lower limits of $N$, respectively (Figure 6A, shaded areas). For this calculation, it is assumed that each bacterium harbors a single coxL operon and that one cfu corresponds to a unique viable cell. Considering the facts that some bacteria possess two coxL operons, the potential impact of cultivation conditions on CO uptake activity and the possibility that bacterial colonies arise from cell aggregates, this calculation provided a rough estimate of theoretical carboxydovore populations in soil. Nevertheless, with the exception of the abundance of $\delta$-Proteobacteria coxL sequences in maize monoculture where qPCR data were below theoretical estimates, there

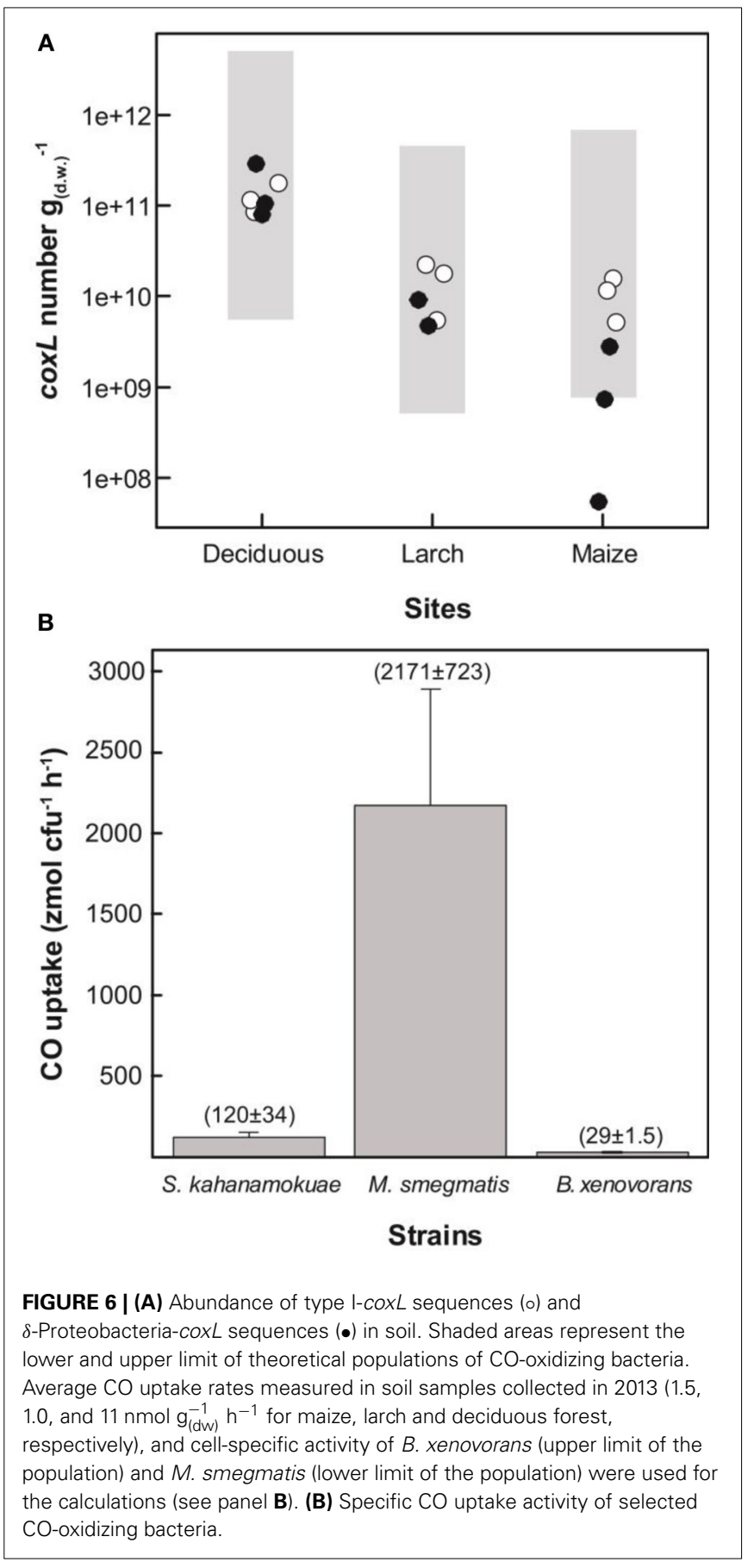

was an agreement between theoretical populations and qPCR data (Figure 6A).

\section{DISCUSSION}

Land-use change exerts strong impact on biogeochemical cycles and soil microbial communities. These environmental pressures are especially marked for biogeochemical processes involving specific metabolisms, restricted to specialist microbes. For instance, afforestation of bog and grassland altered methanotrophic bacteria communities structure in soil, which was directly linked to an 


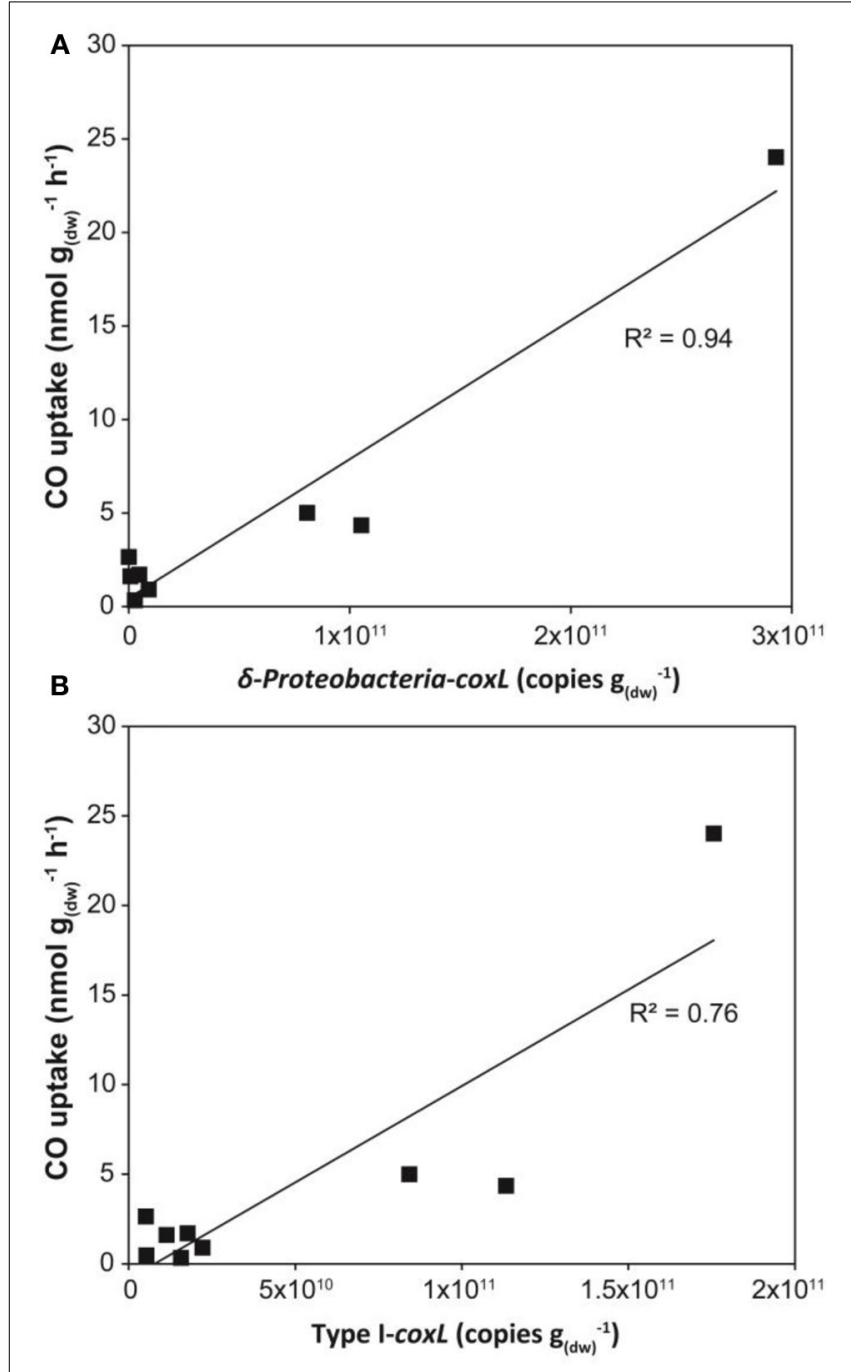

FIGURE 7 | Linear regression modeling dependence of $C O$ uptake activity on the abundance of (A) $\delta$-Proteobacteria-coxL and (B) type I-coxL gene number in soil assessed by qPCR.

enhanced atmospheric methane soil uptake activity in land management experimental stations (Nazaries et al., 2013). Similarly, composition of $\mathrm{N}_{2}$-fixing and denitrifying microbial communities responded to soil physicochemical properties and land-use change, resulting in alteration of nitrous oxide fluxes following afforestation of pastures (Singh et al., 2011). The impact of landuse change on $\mathrm{CO}$ soil-to-air exchanges has been investigated in tropical and temperate climates. Exchanges measured in the field being influenced by temperature and soil water content, these investigations resulted in conflicting observations where agricultural areas represented either more important (King, 2000; King and Hungria, 2002; Pendall et al., 2010) or less important (Moxley and Smith, 1998) sinks for atmospheric CO than native forests. An unanswered question is whether variance of $\mathrm{CO}$ uptake rates observed in soil was due to change in COoxidizing bacteria populations in term of density, specific activity or diversity. Very few field studies combined CO uptake rate measurements with molecular survey of CO-oxidizing bacteria, impairing a clear assessment of the environmental control on their distribution and activity. One notable exception is an extensive survey of CO-oxidizing bacteria accomplished along volcanic deposits, demonstrating a gradient in community structure parallels to CO uptake activity (Weber and King, 2010a). Here, we seek to examine the occurrence of such microbial succession in three neighboring land-use types. The sampling strategy as well as replication of coxL gene libraries and physicochemical analyses were essential to assess the spatial distribution of CO-oxidizing bacteria in the surveyed ecosystems with confidence, in addition to identify the environmental factors best explaining their distribution (Prosser, 2010).

Although conversion of the maize plantation to larch monoculture 15 years ago resulted in significant changes in soil physicochemical properties (Table 1), it exerted no significant impact on CO uptake activity and coxL diversity. However, higher activity and distinct $\mathrm{CO}$-oxidizing bacteria community structure were observed in deciduous forest soil, which emerged from fallow land without human intervention. $\mathrm{CO}$ uptake rates reported in Table 1 were in the same magnitude than the $0.3-50 \mathrm{nmol} \mathrm{g}_{(\mathrm{dw})}^{-1}$ $\mathrm{h}^{-1}$ observed in temperate forest soil samples exposed to atmospheric CO (King, 1999a; Hardy and King, 2001). Soil carbon and nitrogen content were the best variables to explain variations of $\mathrm{CO}$ uptake activity. Even though such relationships have been observed in previous investigations, the mechanistic aspects of the simulation of $\mathrm{CO}$ uptake activity by soil nutrients have received little attention. In the case of nitrogen, correlation does not imply causation since previous investigations excluded nitrogen limitation of the activity. Indeed, ammonium soil amendments caused no influence on CO uptake rate, while nitrite addition resulted in transient inhibition of the activity (King, 1999a; Chan and Steudler, 2006). On the other hand, two main mechanisms have been proposed to explain how soil carbon content enhances $\mathrm{CO}$ uptake activity. Considering the fact that soil carbon content determines microbial biomass and soil respiration activity, it was first proposed that higher soil carbon content supported more abundant communities of CO-oxidizing bacteria (Inman et al., 1971; Moxley and Smith, 1998; King, 1999a). Secondly, an increase of the relative importance of coxL OTU to 16S rRNA gene OTU ratio as a function of soil organic carbon has been noticed, suggesting that soil carbon enhances diversity of COoxidizing bacteria relative to the whole microbial population in soil, resulting in an alteration in CO uptake activity (Weber and King, 2010a). Variation of the abundance and community structure of CO-oxidizing bacteria in response to carbon content in soil are likely induced by the occurrence of a larger pool of $\mathrm{CO}$ in organic rich soils, due to abiotic CO production reactions resulting from thermal- and UV irradiation-mediated soil organic matter decomposition (Conrad and Seiler, 1985; Sanhueza et al., 1998; Derendorp et al., 2011). Therefore, considering that low pH and high carbon content are known to promote CO production in soil (Moxley and Smith, 1998; King, 1999a), sampled deciduous forest may represent a more favorable niche for CO-oxidizing bacteria relative to maize and larch monocultures, resulting in the distribution of coxL sequences and $C O$ uptake activities measured in this study. 
The occurrence of coxL gene sequences belonging to type I and type II groups has been documented in forest, agricultural soils, and volcanic deposits. Investigations undertaken in volcanic deposits showed that type I-coxL diversity was correlated to soil respiration and $\mathrm{CO}$ uptake activity, while no significant correlation was found for type II-coxL sequences (Dunfield and King, 2005). This observation suggested that microbes belonging to type I and type II groups responded differently to environmental factors. Our analysis extends this proposal and unveils that type I-coxL sequences are better proxy for soil CO uptake activity than those encompassing the type II clade. The relative proportion of type I sequences was higher in deciduous forest soil demonstrating the highest CO uptake activity (Figure 4A), while maize and larch monocultures comprised higher proportion of $\operatorname{coxL}$ sequences belonging to type II-CODH. This was further supported by the qPCR assay, showing a direct link between type I-coxL gene number and $\mathrm{CO}$ uptake activity (Figure 7B). These observations, combined with experimental evidence obtained in previous investigations, question the physiological role of the hypothetical type II-CODH in bacteria and the relevance of this genetic marker for $\mathrm{CO}$ uptake activity. In contrast to type I-CODH, functional type II-CODH remains to be experimentally demonstrated. The best characterized type I-CODH is the enzyme from Oligotropha carboxidovorans, a carboxydotrophic bacterium unable to oxidize atmospheric CO due to its low affinity for this substrate (Conrad et al., 1981). Nevertheless, this classical CODH model unveiled critical features on genetic regulation and architecture of the active site (Santiago et al., 1999; Dobbek et al., 2002). Functional type II-CODH was proposed following the PCR-detection of type II $\operatorname{coxL}$ (and no detection of type I-coxL) in Aminobacter sp. COX, demonstrating high affinity CO-uptake activity (King, 2003a). The involvement of type II-CODH in $\mathrm{CO}$ oxidation reaction is however puzzling since the canonical cysteine residue accommodating the copper atom directly involved in the $\mathrm{CO}$ oxidation catalysis (Dobbek et al., 2002) is replaced by a glycine residue in these hypothetical enzymes. Furthermore, characterization of CO oxidation activity in marine Roseobacter spp. revealed that strains harboring type IIcoxL only were not active (Cunliffe, 2010). Genetic investigations are mandatory to assess the physiological role of type II-CODH, but $\operatorname{coxL}$ sequences belonging to functional type I-CODH phylogenetic group appear more relevant to predict CO uptake activity in soil.

Previous soil survey for CO-oxidizing bacteria realized along volcanic deposits, agricultural areas and forests unveiled dominance of type I-cox $L$ sequences belonging to $\alpha$-, $\beta$-Proteobacteria, Actinobacteria, and Chloroflexi, with each group represented by strains for which CO uptake activity has been demonstrated (King and Weber, 2007). The $\alpha$-Proteobacteria cluster comprises the model CO-oxidizing bacterium Oligotropha carboxidovorans able to grow using $\mathrm{CO}$ as only carbon source, as well as Bradyrhizobium, Roseobacter, Ruegeria, and Stappia representatives. Among these, Stappia isolates displayed a high affinity $\mathrm{CO}$ oxidation activity and thus, the ability to oxidize ambient and sub-ambient levels of CO (Weber and King, 2007). Bradyrhizobium, Roseobacter, and Ruegeria representatives were also shown to oxidize $\mathrm{CO}$, but their affinity for $\mathrm{CO}$ has not been reported (King, 2003a; Tolli et al., 2006; Cunliffe, 2010). Oxidation of atmospheric $\mathrm{CO}$ in $\beta$-Proteobacteria mainly has been examined in Burkholderia. Metabolism of CO was unevenly distributed in this genus, with more prevalence in strains thriving in the rhizosphere, and $\mathrm{CO}$ oxidation rates were shown to be higher when heterotrophic growth substrates were limiting (King, 2003a; Weber and King, 2012). Actinobacteria were also shown to oxidize atmospheric $\mathrm{CO}$, with mycobacterium as the most extensively studied group (King, 2003b; Song et al., 2010; Kim and Park, 2012). Finally, recent investigations demonstrated that capacity for $\mathrm{CO}$ uptake is a common trait among the Ktedonobacteria, in agreement with the detection of coxL sequence affiliated to this taxonomic group in cinder volcanic deposits (Weber and King, 2010a; King and King, 2014). These observations suggest that carboxydovore bacteria responsible for the measured $\mathrm{CO}$ uptake activity harbored the type I-coxL sequences detected in this study. Comparison of our analysis with previous investigations combining type I-coxL and CO uptake activity analysis suggests that environmental conditions select different groups of carboxydovores in soil. Indeed, analysis of a vegetation chronosequence in Hawaii highlighted an increase in $\beta$-Proteobacteria-cox $L$ sequences in sites characterized by higher $\mathrm{CO}$ uptake activity, suggesting the importance of this taxonomic group for CO uptake activity (Weber and King, 2010a,b; King and King, 2014). It was proposed that COoxidizing Burkholderia spp. were favored with plant development, benefiting of root exudates for growth and elevated CO levels as energy source in the rhizosphere (King and Crosby, 2002; Weber and King, 2012). In this study, assignation of type I-coxL clone sequences to taxonomic groups showed a higher relative abundance of $\delta$-Proteobacteria-cox $L$ sequences in deciduous forest showing the maximal CO uptake activity (Figure 4B). Rare sequences affiliated to this cluster were detected in bare soil of volcanic deposits, with $H$. ochraceum as the closest cultivated relative (Weber and King, 2010a). We confirmed the ability of $H$. ochraceum to oxidize atmospheric $\mathrm{CO}$, but the origin of detected $\delta$-Proteobacteria-coxL sequences remains unknown as they share less than $75 \%$ similarity score with $H$. ochraceum. Although this carboxydovore is halophile, myxobacteria related to this genus are diverse and were detected in recent soil metagenomic surveys (Luo et al., 2014; Zhou et al., 2014). Myxobacteria are ubiquitous in soil and are characterized by the formation of fruiting bodies enclosing stress-resistant myxospores structures as well as their ability to metabolize recalcitrant carbon macromolecules and feed on prey microorganisms through exoenzyme secretion (Reichenbach, 1999; Dawid, 2000). As no other genome sequence of $\delta$-Proteobacteria was shown to harbor $\operatorname{coxL}$ gene sequence in our genome data mining, isolation of more representatives within this taxonomic group deserves peculiar attention to investigate their contribution in the biogeochemical cycle of CO.

This article provides the first absolute abundance of type I- $\operatorname{cox} L$ sequences in soil. The abundance of type I sequences determined in this study was higher than the $10^{8}$ genes $\mathrm{g}^{-1}$ reported in volcanic deposits using a $\mathrm{qPCR}$ assay specific to Burkholderia (Weber and King, 2010b). Analysis of cell-specific CO oxidation activity in three selected carboxydovores was undertaken to assess reliability of the qPCR assays. There was a general agreement 
with the coxL gene numbers and theoretical populations of carboxydovores bacteria necessary to explain the CO uptake activity measured in soil. The broad range in theoretical population predictions was explained by variance in specific $\mathrm{CO}$ oxidation activities, varying from 29 to $2171 \mathrm{zmol} \mathrm{cfu}^{-1} \mathrm{~h}^{-1}$ among the tested isolates. Even though potential variability induced by the formation of cfu from cell aggregates cannot be excluded, similar variations were observed in previous comparison of CO uptake activity in carboxydovore bacteria. Indeed, activity measured in axenic cultures of Stappia sp. and Stenotrophomonas sp. varied between 6 and $100 \mu \mathrm{g} \mathrm{CO} \mathrm{mg}_{\text {(protein) }}^{-1} \mathrm{~h}^{-1}$ (King, 2003a). Substrate affinity, cell physiology and metabolic activity are potential explanations for such variability in specific activity estimates (Knief and Dunfield, 2005) and will need more attention in future investigations to address how CO shapes microbial communities in the environment. Gene libraries suggested a more pronounced enrichment of carboxydovores belonging to $\delta$-Proteobacteria in deciduous forest relative to both monocultures, but a qPCR assay targeting this specific subpopulation contradicted this observation. Incongruence of theoretical populations of carboxydovores and the abundance of $\delta$-Proteobacteria-cox $L$ sequences estimated by qPCR in maize plantation highlights the fact that carboxydovores belonging to this class cannot be used as an universal proxy for $\mathrm{CO}$ uptake activity in soil, due to the response of CO-oxidizer to their environment resulting in the dominance of different taxonomic groups of carboxydovores in contrasting ecosystems (Dunfield and King, 2005; King et al., 2008; Weber and King, 2010a). Considering this observation, we recommend the broader qPCR assay we developed, targeting the whole type I-coxL cluster, to test the relevance of this molecular marker in predicting CO uptake activity in soil for future investigations. These additional efforts, including samples displaying a broad range of $\mathrm{CO}$ uptake activity, are necessary because the regression analysis reported in Figure 7B was largely supported by the high $\mathrm{CO}$ uptake activity and $\operatorname{coxL}$ abundance in deciduous forest.

In conclusion, this work demonstrates the non-random distribution of CO-oxidizing bacteria in contrasting ecosystems, with land-use as a driver of diversification for this functional group. We showed that composition and abundance of CO-oxidizing bacteria community structure reflected CO uptake activity in soil. The combination of two complementary methodological approaches applied to independent soil surveys provides strong support and confidence to these observations. In contrast to the functional type I-CODH, the physiological role of type II-CODH remains to be defined as their distribution does not appear directly linked to $\mathrm{CO}$ uptake activity in soil and $\mathrm{CO}$-oxidizing bacteria. Although this study was limited to three ecosystems, the soil survey resulted in the development of a reliable qPCR assay targeting presumptive CO-oxidizing bacteria in soil. A more extensive survey, including more ecosystem types is however necessary to challenge this quantitative indicator to predict $\mathrm{CO}$ oxidation rate in the environment. Finally, in addition to describe diversity of carboxydovore bacteria, this work suggests this functional group represents a significant proportion of soil microbiota. For instance, density of high affinity $\mathrm{H}_{2}$-oxidizing bacteria responsible for $80 \%$ of the global loss of atmospheric $\mathrm{H}_{2}$ is typically between $10^{6}$ and $10^{8}$ cells $\mathrm{g}_{(\text {soil-dw) }}^{-1}$, as estimated by qPCR targeting the gene $h h y L$ specifying the large subunit of their high affinity hydrogenase (Constant et al., 2011b). These microorganisms compensate their low abundance by a much higher cell specific activity than carboxydovores, oxidizing $\mathrm{H}_{2}$ at a rate of $2-3 \mathrm{amol} \mathrm{cfu}^{-1} \mathrm{~h}^{-1}$ in some streptomycetes (Constant et al., 2011a). Because carboxydovores are abundant and taxonomically diverse, they should exert a significant impact on soil microbiota and biological processes. Future work thus should focus on the interactions of CO-oxidizing bacteria with microorganisms involved in other globally important biogeochemical functions. In addition to alter global budget of atmospheric CO, alteration of the distribution and activity of this functional group may have significant impacts on ecosystem services.

\section{AUTHOR CONTRIBUTIONS}

Liliana Quiza and Isabelle Lalonde performed the experiments. Liliana Quiza, Isabelle Lalonde, and Claude Guertin participated to manuscript redaction. Claude Guertin introduced Philippe Constant to the sampling site. Philippe Constant designed the research and wrote the article.

\section{ACKNOWLEDGMENTS}

This research was supported by a grant from the Fonds de Recherche du Québec-Nature et Technologies (FRQNT-New Researchers Start Up Program) to Philippe Constant. The work of Isabelle Lalonde was supported by a NSERC_-Undergraduate Student Research Awards and a Graduate student scholarship from the Fondation Universitaire Armand-Frappier INRS.

\section{SUPPLEMENTARY MATERIAL}

The Supplementary Material for this article can be found online at: http://www.frontiersin.org/journal/10.3389/fmicb. 2014.00271/abstract

\section{REFERENCES}

Altschul, S. F., Gish, W., Miller, W., Myers, E. W., and Lipman, D. J. (1990). Basic local alignment search tool. J. Mol. Biol. 215, 403-410. doi: 10.1016/S00222836(05)80360-2

Assonov, S., Brenninkmeijer, C., Jöckel, P., Mulvaney, R., Bernard, S., and Chappellaz, J. (2007). Evidence for a CO increase in the SH during the 20th century based on firn air samples from Berkner Island, Antarctica. Atmos. Chem. Phys. 7, 295-308. doi: 10.5194/acp-7-295-2007

Blanchet, F. G., Legendre, P., and Borcard, D. (2008). Forward selection of explanatory variables. Ecology 89, 2623-2632. doi: 10.1890/07-0986.1

Borcard, D., Gillet, F., and Legendre, P. (2011). Numerical Ecology with R. New York, NY: Springer.

Brankatschk, R., Bodenhausen, N., Zeyer, J., and Bürgmann, H. (2012). Simple absolute quantification method correcting for quantitative PCR efficiency variations for microbial community samples. Appl. Environ. Microbiol. 78, 4481-4489. doi: 10.1128/AEM.07878-11

Chan, A. S. K., and Steudler, P. A. (2006). Carbon monoxide uptake kinetics in unamended and long-term nitrogen-amended temperate forest soils. FEMS Microbiol. Ecol. 57, 343-354. doi: 10.1111/j.1574-6941.2006.00127.x

Chan, L. Y., Lau, W. L., Zou, S. C., Cao, Z. X., and Lai, S. C. (2002). Exposure level of carbon monoxide and respirable suspended particulate in public transportation modes while commuting in urban area of Guangzhou, China. Atmos. Environ. 36, 5831-5840. doi: 10.1016/S1352-2310(02)00687-8

Chevalier, A., Gheusi, F., Attié, J.-L., Delmas, R., Zbinden, R., Athier, G., et al. (2008). Carbon monoxide observations from ground stations in France and Europe and long trends in the free troposphere. Atmos. Chem. Phys. Discuss. 8, 3313-3356. doi: 10.5194/acpd-8-3313-2008 
Conrad, R. (1994). Compensation concentration as critical variable for regulating the flux of trace gases between soil and atmosphere. Biogeochemistry 27, 155-170. doi: 10.1007/BF00000582

Conrad, R., Meyer, O., and Seiler, W. (1981). Role of carboxydobacteria in consumption of atmospheric carbon monoxide by soil. Appl. Environ. Microbiol. 42, 211-215.

Conrad, R., and Seiler, W. (1985). Influence of temperature, moisture, and organic carbon on the flux of $\mathrm{H}_{2}$ and $\mathrm{CO}$ between soil and atmosphere: field studies in subtropical regions. J. Geophys. Res. Atmos. 90, 5699-5709. doi: 10.1029/JD090iD03p05699

Constant, P., Chowdhury, S. P., Hesse, L., and Conrad, R. (2011a). Co-localization of atmospheric $\mathrm{H}_{2}$ oxidation activity and high affinity $\mathrm{H}_{2}$-oxidizing bacteria in non-axenic soil and sterile soil amended with Streptomyces sp. PCB7. Soil Biol. Biochem. 43, 1888-1893. doi: 10.1016/j.soilbio.2011.05.009

Constant, P., Chowdhury, S. P., Hesse, L., Pratscher, J., and Conrad, R. (2011b). Genome data mining and soil survey for the novel group 5 [NiFe]-hydrogenase to explore the diversity and ecological importance of presumptive high affinity $\mathrm{H}_{2}$-oxidizing bacteria. Appl. Environ. Microbiol. 77, 6027-6035. doi: 10.1128/AEM.00673-11

Cunliffe, M. (2010). Correlating carbon monoxide oxidation with cox genes in the abundant marine Roseobacter clade. ISME J. 5, 685-691. doi: 10.1038 /ismej.2010.170

Daniel, J. S., and Solomon, S. (1998). On the climate forcing of carbon monoxide. J. Geophys. Res. Atmos. 103, 13249-13260. doi: 10.1029/98JD00822

Dawid, W. (2000). Biology and global distribution of myxobacteria in soils. FEMS Microbiol. Rev. 24, 403-427. doi: 10.1111/j.1574-6976.2000.tb00548.x

Decoste, N. J., Gadkar, V. J., and Filion, M. (2011). Relative and absolute quantitative real-time PCR-based quantifications of $h c n C$ and phlD gene transcripts in natural soil spiked with Pseudomonas sp. strain LBUM300. Appl. Environ. Microbiol. 77, 41-47. doi: 10.1128/AEM.01387-10

Deer, D. M., Lampel, K. A., and González-Escalona, N. (2010). A versatile internal control for use as DNA in real-time PCR and as RNA in real-time reverse transcription PCR assays. Lett. Appl. Microbiol. 50, 366-372. doi: 10.1111/j.1472765X.2010.02804.x

Degelmann, D. M., Borken, W., Drake, H. L., and Kolb, S. (2010). Different atmospheric methane-oxidizing communities in European beech and Norway spruce soils. Appl. Environ. Microbiol. 76, 3228-3235. doi: 10.1128/AEM.02730-09

Derendorp, L., Quist, J. B., Holzinger, R., and Röckmann, T. (2011). Emissions of $\mathrm{H}_{2}$ and $\mathrm{CO}$ from leaf litter of Sequoiadendron giganteum, and their dependence on UV radiation and temperature. Atmos. Environ. 45, 7520-7524. doi: 10.1016/j.atmosenv.2011.09.044

Dixon, P. (2003). VEGAN, a package of R functions for community ecology. J. Veg. Sci. 14, 927-930. doi: 10.1111/j.1654-1103.2003.tb02228.x

Dobbek, H., Gremer, L., Kiefersauer, R., Huber, R., and Meyer, O. (2002). Catalysis at a dinuclear $[\mathrm{CuSMo}(\mathrm{O}) \mathrm{OH}]$ cluster in a $\mathrm{CO}$ dehydrogenase resolved at 1.1-Å resolution. Proc. Natl. Acad. Sci. U.S.A. 99, 15971-15976. doi: $10.1073 /$ pnas. 212640899

Dunfield, K. E., and King, G. M. (2005). Analysis of the distribution and diversity in recent Hawaiian volcanic deposits of a putative carbon monoxide dehydrogenase large subunit gene. Environ. Microbiol. 7, 1405-1412. doi: 10.1111/j.14622920.2005.00827.x

Edgar, R. C. (2004). MUSCLE: multiple sequence alignment with high accuracy and high throughput. Nucleic Acids Res. 32, 1792-1797. doi: 10.1093/nar/gkh340

Elghamry, W., and Elashkar, M. (1962). Simplified textural classification triangles. Soil Sci. Soc. Am. J. 26, 612-613. doi: 10.2136/sssaj1962.03615995002600060028x

Fudou, R., Jojima, Y., Iizuka, T., and Yamanaka, S. (2002). Haliangium ochraceum gen. nov., sp. nov. and Haliangium tepidum sp. nov.: novel moderately halophilic myxobacteria isolated from coastal saline environments. J. Gen. Appl. Microbiol. 48, 109-115. doi: 10.2323/jgam.48.109

Hardy, K. R., and King, G. M. (2001). Enrichment of high-affinity CO oxidizers in Maine forest soil. Appl. Environ. Microbiol. 67, 3671-3676. doi: 10.1128/AEM.67.8.3671-3676.2001

Hille, R. (2005). Molybdenum-containing hydroxylases. Arch. Biochem. Biophys. 433, 107-116. doi: 10.1016/j.abb.2004.08.012

Holloway, T., and Levy, I. (2000). Global distribution of carbon monoxide. J. Geophys. Res. 105, 12123-12147. doi: 10.1029/1999JD901173

Inman, R. E., Ingersoll, R. B., and Levy, E. A. (1971). Soil: a natural sink for carbon monoxide. Science 172, 1229-1231. doi: 10.1126/science.172.3989.1229
Kim, Y. M., and Park, S. W. (2012). Microbiology and genetics of CO utilization in mycobacteria. Antonie Van Leeuwenhoek 101, 685-700. doi: 10.1007/s10482012-9698-y

Kimble, L., Mandelco, L., Woese, C., and Madigan, M. (1995). Heliobacterium modesticaldum, sp. nov., a thermophilic heliobacterium of hot springs and volcanic soils. Arch. Microbiol. 163, 259-267. doi: 10.1007/BF00393378

King, C. E., and King, G. M. (2014). Description of Thermogemmatispora carboxidivorans sp. nov., a novel carbon monoxide-oxidizing member of the Ktedonobacteria isolated from a geothermally-heated biofilm, and analysis of carbon monoxide oxidation by members of the Ktedonobacteria. Int. J. Syst. Evol. Microbiol. 64, 1244-1251. doi: 10.1099/ijs.0.059675-0

King, G. M. (1999a). Attributes of atmospheric carbon monoxide oxidation by Maine forest soils. Appl. Environ. Microbiol. 65, 5257-5264.

King, G. M. (1999b). Characteristics and significance of atmospheric carbon monoxide consumption by soils. Chemosphere Global Change Sci. 1, 53-63. doi: 10.1016/S1465-9972(99)00021-5

King, G. M. (2000). Land use impacts on atmospheric carbon monoxide consumption by soils. Global Biogeochem. Cycles 14, 1161-1172. doi: 10.1029/2000GB001272

King, G. M. (2003a). Molecular and culture-based analyses of aerobic carbon monoxide oxidizer diversity. Appl. Environ. Microbiol. 69, 7257-7265. doi: 10.1128/AEM.69.12.7257-7265.2003

King, G. M. (2003b). Uptake of carbon monoxide and hydrogen at environmentally relevant concentrations by mycobacteria. Appl. Environ. Microbiol. 69, 7266-7272. doi: 10.1128/AEM.69.12.7266-7272.2003

King, G. M., and Crosby, H. (2002). Impacts of plant roots on soil CO cycling and soil-atmosphere CO exchange. Glob. Chang. Biol. 8, 1085-1093. doi: 10.1046/j.1365-2486.2002.00545.x

King, G. M., and Hungria, M. (2002). Soil-atmosphere CO exchanges and microbial biogeochemistry of $\mathrm{CO}$ transformations in a Brazilian agricultural ecosystem. Appl. Environ. Microbiol. 68, 4480-4485. doi: 10.1128/AEM.68.9.4480-4485.2002

King, G. M., and Weber, C. F. (2007). Distribution, diversity and ecology of aerobic CO-oxidizing bacteria. Nat. Rev. Microbiol. 5, 107-118. doi: 10.1038/nrmicro1595

King, G. M., Weber, C. F., Nanba, K., Sato, Y., and Ohta, H. (2008). Atmospheric $\mathrm{CO}$ and hydrogen uptake and CO oxidizer phylogeny for Miyake-Jima, Japan volcanic deposits. Microbes Environ. 23, 299-305. doi: 10.1264/jsme2. ME08528

Knief, C., and Dunfield, P. F. (2005). Response and adaptation of different methanotrophic bacteria to low methane mixing ratios. Environ. Microbiol. 7, 1307-1317. doi: 10.1111/j.1462-2920.2005.00814.x

Legendre, P., and Gallagher, E. (2001). Ecologically meaningful transformations for ordination of species data. Oecologia 129, 271-280. doi: 10.1007/s004420100716

Lozupone, C., and Knight, R. (2005). UniFrac: a new phylogenetic method for comparing microbial communities. Appl. Environ. Microbiol. 71, 8228-8235. doi: 10.1128/AEM.71.12.8228-8235.2005

Luo, C., Rodriguez-R, L. M., Johnston, E. R., Wu, L., Cheng, L., Xue, K., et al. (2014). Soil microbial community responses to a decade of warming as revealed by comparative metagenomics. Appl. Environ. Microbiol. 80, 1777-1786. doi: 10.1128/AEM.03712-13

Mörsdorf, G., Frunzke, K., Gadkari, D., and Meyer, O. (1992). Microbial growth on carbon monoxide. Biodegradation 3, 61-82. doi: 10.1007/BF00189635

Moxley, J. M., and Smith, K. A. (1998). Factors affecting utilisation of atmospheric CO by soils. Soil Biol. Biochem. 30, 65-79. doi: 10.1016/S0038-0717(97)00095-3

Nazaries, L., Pan, Y., Bodrossy, L., Baggs, E. M., Millard, P., Murrell, J. C., et al. (2013). Evidence of microbial regulation of biogeochemical cycles from a study on methane flux and land use change. Appl. Environ. Microbiol. 79, 4031-4040. doi: 10.1128/AEM.00095-13

Novelli, P. C., Masarie, K. A., and Lang, P. M. (1998). Distributions and recent changes of carbon monoxide in the lower troposphere. J. Geophys. Res. Atmos. 103, 19015-19033. doi: 10.1029/98JD01366

Novelli, P. C., Masarie, K. A., Lang, P. M., Hall, B. D., Myers, R. C., and Elkins, J. W. (2003). Reanalysis of tropospheric CO trends: effects of the 1997-1998 wildfires. J. Geophys. Res. Atmos. 108, 4464. doi: 10.1029/2002JD003031

Palmer, K., Drake, H. L., and Horn, M. A. (2009). Genome-derived criteria for assigning environmental narG and nos $Z$ sequences to operational taxonomic units of nitrate reducers. Appl. Environ. Microbiol. 75, 5170-5174. doi: 10.1128/AEM.00254-09 
Pendall, E., Schwendenmann, L., Rahn, T., Miller, J. B., Tans, P. P., and White, J. W. C. (2010). Land use and season affect fluxes of $\mathrm{CO}_{2}, \mathrm{CH}_{4}, \mathrm{CO}, \mathrm{N}_{2} \mathrm{O}, \mathrm{H}_{2}$ and isotopic source signatures in Panama: evidence from nocturnal boundary layer profiles. Glob. Chang. Biol. 16, 2721-2736. doi: 10.1111/j.13652486.2010.02199.x

Prosser, J. I. (2010). Replicate or lie. Environ. Microbiol. 12, 1806-1810. doi: 10.1111/j.1462-2920.2010.02201.x

R Development Core Team. (2008). R: A Language and Environment for Statistical Computing. Vienna: R.F.F.S. Computing.

Reichenbach, H. (1999). The ecology of the myxobacteria. Environ. Microbiol. 1, 15-21. doi: 10.1046/j.1462-2920.1999.00016.x

Sambrook, J., and Russell, D. W. (2001). Molecular Cloning: A Laboratory Manual. Woodbury, MN: CSHL Press.

Sanhueza, E., Dong, Y., Lobert, J., and Crutzen, P. (1998). Carbon monoxide uptake by temperate forest soils: the effects of leaves and humus layers. Tellus B 50, 51-58. doi: 10.1034/j.1600-0889.1998.00004.x

Santiago, B., Schübel, U., Egelseer, C., and Meyer, O. (1999). Sequence analysis, characterization and $\mathrm{CO}$-specific transcription of the cox gene cluster on the megaplasmid pHCG3 of Oligotropha carboxidovorans. Gene 236, 115-124. doi: 10.1016/S0378-1119(99)00245-0

Schloss, P. D., Westcott, S. L., Ryabin, T., Hall, J. R., Hartmann, M., Hollister, E. B., et al. (2009). Introducing Mothur: open-source, platform-independent, community-supported software for describing and comparing microbial communities. Appl. Environ. Microbiol. 75, 7537-7541. doi: 10.1128/AEM. 01541-09

Singh, B. K., Tate, K., Thomas, N., Ross, D., and Singh, J. (2011). Differential effect of afforestation on nitrogen-fixing and denitrifying communities and potential implications for nitrogen cycling. Soil Biol. Biochem. 43, 1426-1433. doi: 10.1016/j.soilbio.2011.03.007

Song, T., Park, S. W., Park, S.-J., Kim, J. H., Yu, J. Y., Oh, J.-I., et al. (2010). Cloning and expression analysis of the duplicated genes for carbon monoxide dehydrogenase of Mycobacterium sp. strain JC1 DSM 3803. Microbiology 156, 999-1008. doi: 10.1099/mic.0.034769-0

Tamura, K., Dudley, J., Nei, M., and Kumar, S. (2007). MEGA4: molecular evolutionary genetics analysis (MEGA) software version 4.0. Mol. Biol. Evol. 24, 1596-1599. doi: 10.1093/molbev/msm092

Tolli, J. D., Sievert, S. M., and Taylor, C. D. (2006). Unexpected diversity of bacteria capable of carbon monoxide oxidation in a coastal marine environment, and contribution of the Roseobacter-associated clade to total CO oxidation. Appl. Environ. Microbiol. 72, 1966-1973. doi: 10.1128/AEM.72.3.1966-1973.2006

Vasileiadis, S., Puglisi, E., Arena, M., Cappa, F., Van Veen, J. A., Cocconcelli, P. S., et al. (2013). Soil microbial diversity patterns of a lowland spring environment. FEMS Microbiol. Ecol. 86, 172-184. doi: 10.1111/1574-6941.12150

Weber, C. F., and King, G. M. (2007). Physiological, ecological, and phylogenetic characterization of Stappia, a marine CO-oxidizing bacterial genus. Appl. Environ. Microbiol. 73, 1266-1276. doi: 10.1128/AEM.01724-06

Weber, C. F., and King, G. M. (2010a). Distribution and diversity of carbon monoxide-oxidizing bacteria and bulk bacterial communities across a succession gradient on a Hawaiian volcanic deposit. Environ. Microbiol. 12, 1855-1867. doi: 10.1111/j.1462-2920.2010.02190.x

Weber, C. F., and King, G. M. (2010b). Quantification of Burkholderia coxL genes in Hawaiian volcanic deposits. Appl. Environ. Microbiol. 76, 2212-2217. doi: 10.1128/AEM.01861-09

Weber, C. F., and King, G. M. (2012). The phylogenetic distribution and ecological role of carbon monoxide oxidation in the genus Burkholderia. FEMS Microbiol. Ecol. 79, 167-175. doi: 10.1111/j.1574-6941.2011.01206.x

Zhou, X.-W., Li, S.-G., Li, W., Jiang, D.-E., Han, K., and Wu, Z.-H. (2014). Myxobacterial community is a predominant and highly diverse bacterial group in soil niches. Environ. Microbiol. Rep. 6, 45-56. doi: 10.1111/1758-2229.12107

Conflict of Interest Statement: The authors declare that the research was conducted in the absence of any commercial or financial relationships that could be construed as a potential conflict of interest.

Received: 18 March 2014; accepted: 19 May 2014; published online: 12 June 2014. Citation: Quiza L, Lalonde I, Guertin C and Constant P (2014) Land-use influences the distribution and activity of high affinity CO-oxidizing bacteria associated to type I-coxL genotype in soil. Front. Microbiol. 5:271. doi: 10.3389/fmicb.2014.00271 This article was submitted to Terrestrial Microbiology, a section of the journal Frontiers in Microbiology.

Copyright (c) 2014 Quiza, Lalonde, Guertin and Constant. This is an open-access article distributed under the terms of the Creative Commons Attribution License (CC BY). The use, distribution or reproduction in other forums is permitted, provided the original author(s) or licensor are credited and that the original publication in this journal is cited, in accordance with accepted academic practice. No use, distribution or reproduction is permitted which does not comply with these terms. 